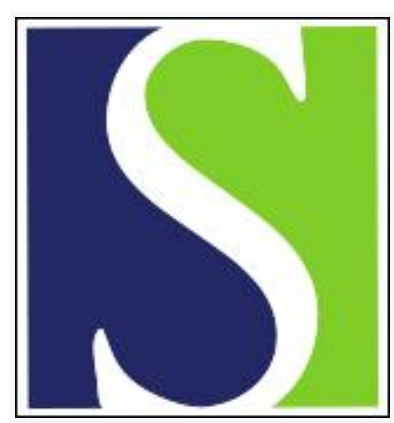

Scand J Work Environ Health 1984;10(3):163-169

https://doi.org/10.5271/sjweh.2347

Issue date: Jun 1984

Analytical, occupational and toxicologic aspects of the degradation products of polypropylene plastics.

by Frostling $\mathrm{H}$, Hoff A, Jacobsson S, Pfaffli P, Vainiotalo S, Zitting A

This article in PubMed: www.ncbi.nlm.nih.gov/pubmed/6474110

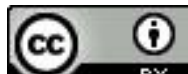




\title{
Analytical, occupational and toxicologic aspects of the degradation products of polypropylene plastics
}

\author{
by Harald Frostling, PhD, ${ }^{1}$ Ariel Hoff, PhD, ${ }^{2,3}$ Sven Jacobsson, MSc, ${ }^{4}$ Pirkko Pfäffli, MSc, ${ }^{5}$ \\ Sinikka Vainiotalo, MSc, ${ }^{5}$ Antti Zitting, D Techn, ${ }^{5}$
}

\begin{abstract}
FROSTLING H, HOFF A, JACOBSSON S, PFÄFFLI P, VAINIOTALO S, ZITTING A. Analytical, occupational and toxicologic aspects of the degradation products of polypropylene plastics. Scand $J$ Work Environ Health 10 (1984) 163-169. Thermooxidative degradation of polypropylene (PP) at close to the industrial processing temperatures was studied with thermogravimetric analysis, infrared spectroscopy, and gas chromatography-mass spectrometry (GC-MS). GC-MS allowed identification of 47 volatile degradation products. Formaldehyde, acetaldehyde, $\alpha$-methylacrolein, acetic acid, and acetone were the major products. Antioxidants markedly slowed down the degradation of polypropylene and the evolution of the degradation products. The relative amounts of the oxidized products were mostly independent of the degradation temperature or the type of antioxidant. Measurements in the plastics industry revealed low airborne concentrations of individual volatile products. The concentration of aerosols, which infrared analysis showed to resemble paraffin fumes, was significant and probably the most important hygienic hazard. The biochemical parameters (the consumption of protecting sulfhydryl groups and the effects on foreign compound metabolism) indicated that the degradation products are biologically reactive, affecting the balance of normal metabolism in exposed animals.
\end{abstract}

Key terms: plastics processing.

Polypropylene (PP) is one of the most widely used thermoplastics, and its production shows the greatest growth. The annual increase in its consumption has been estimated at $6 \%$ for $1981-1991$. The production of low-density polyethylene and polyvinyl chloride shows an annual expansion of $3 \%$ (7). If used without antioxidants, PP is susceptible to oxidation, with impairment of its mechanical properties and an increase in the emission of volatile compounds in the processing. The emitted compounds may contaminate the work atmosphere and present a health hazard for workers. PP is usually protected with antioxidants. However, the processing temperatures can be high $\left(200-300^{\circ} \mathrm{C}\right)$ in many techniques, and the protection might not be effective on the surfaces of readyformed products exposed to air. Most studies on the

\footnotetext{
' Swedish Employers' Confederation, S-103 30 Stockholm, Sweden.

2 Department of Polymer Technology, The Royal Institute of Technology, S-100 44 Stockholm, Sweden.

3 Present address: AGA AB, Gas Innovation, S-181 81 Lindingö, Sweden.

4 Department of Analytical Chemistry, University of Stockholm, S-106 91 Stockholm, Sweden.

5 Department of Industrial Hygiene and Toxicology, Institute of Occupational Health, SF-00290 Helsinki, Finland.

(Authors listed in alphabetical order)
}

Reprint requests to: Dr A Zitting, Institute of Occupational Health, Haartmaninkatu 1, SF-00290 Helsinki, Finland. thermal oxidation of PP have been performed at temperatures below $170^{\circ} \mathrm{C}(1,4)$, a level rarely used in industrial processing.

This work is a part of a series of studies started with polyethylene and styrene-containing thermoplastics (3). The degradation of PP was studied at temperatures close to those of industrial processes to reveal the kinds of volatile products formed and their concentrations under normal industrial conditions. The effect of antioxidants on thermal oxidative degradation was evaluated, as well as the biochemical effects on animals exposed to the degradation products.

\section{Materials and methods}

Analysis of volatile degradation products

Shell polypropylene KM 6100 (for general purposes, molding quality) without additives was used. This substance is a crystalline, isotactic polymer with the following characteristics: density $0.905 \mathrm{~g} / \mathrm{cm}^{3}$ and melt index $3.5\left(2.16 \mathrm{~kg}\right.$ at $\left.230^{\circ} \mathrm{C}\right)$. Polymer films $(50$ $\mu \mathrm{m}$ ) were molded at $210-220^{\circ} \mathrm{C}$ for $60-90 \mathrm{~s}$ in the analytical studies. The antioxidants are given in table 1. These antioxidants were commercial products supplied by Ciba-Geigy (Switzerland). They [1 \% (weight/weight)] were blended with PP as follows: The antioxidant was dissolved in acetone or 
Table 1. Antioxidants used with polypropylene.

\begin{tabular}{llc}
\hline Trade name & Chemical name & Designation \\
\hline Irganox 1010 & $\begin{array}{l}\text { Pentaerythryl-tetracis-3-(3,5- } \\
\text { di-tert-butyl-4-hydroxyphenyl)- } \\
\text { propionate } \\
\text { Molecular weight 1178 }\end{array}$ & AO1 \\
Irganox 1035 & $\begin{array}{l}\text { 2,2-Thiodiethylbis-3-(3,4-di- } \\
\text { tert-butyl-4-hydroxypheny)- } \\
\text { propionate } \\
\text { Molecular weight 643 }\end{array}$ & AO2 \\
Irganox 565 & $\begin{array}{l}\text { 4-\{[4,6-Bis(octylthio)-1,3,5- } \\
\text { triazin-2-yl] amino\}-2,6-bis(di- } \\
\text { methylethyl)phenol } \\
\text { Molecular weight 589 }\end{array}$ & AO3 \\
Irganox B 561 & $\begin{array}{l}\text { Mixture of Irganox 1010 } \\
\text { (1 part) and Irgafos 168 (an } \\
\text { organophosphite) } \\
\text { Molecular weight 647 (4 parts) }\end{array}$ & AO4 \\
\hline
\end{tabular}

Table 3. Evolution of oxygen-containing products $(\mathrm{mg} / \mathrm{kg}$ of plastic) during the thermooxidative degradation of polypropylene in $2 \mathrm{~min}$.

\begin{tabular}{lrr}
\hline & \multicolumn{2}{c}{$\begin{array}{c}\text { Degradation } \\
\text { temperature }\end{array}$} \\
\cline { 2 - 3 } Compound & $220^{\circ} \mathrm{C}$ & $280^{\circ} \mathrm{C}$ \\
\hline Aldehydes & & \\
Formaldehyde & 480 & 12,100 \\
Acetaldehyde & 1,100 & 22,900 \\
$\alpha$-Methylacrolein & 390 & 8,820 \\
Ketones & & \\
Acetone & 700 & 12,350 \\
1-Hydroxy-2-propanone & 74 & 600 \\
2-Butanone & - & 600 \\
2-Pentanone & 120 & 2,800 \\
Methylcyclopropylketone & 70 & 1,700 \\
Acetylacetone & 600 & 5,500 \\
Ethers & & \\
2,5-Dimethylfuran & & \\
Acids & 70 & 260 \\
Formic acid & & \\
Acetic acid & - & 2,600 \\
Alcohols & 560 & 12,800 \\
Methanol & & \\
2-Methyl-2-propen-1-ol & - & 230 \\
Water & - & 954,000 \\
\hline & 48,600 & \\
\hline
\end{tabular}

in chloroform, and the solution was evenly sprayed onto the surfaces of two symmetrical pieces of PP film. The solvent was allowed to evaporate, and the films were placed face-to-face and molded at $210^{\circ} \mathrm{C}$. The resulting film was cut into pieces and molded again. The molding and cutting procedure was repeated three times. Samples without antioxidants were treated similarly.

The thermogravimetric analysis and the gas chromatographic-mass spectrometric (GC-MS) methodo-
Table 2. Products of polypropylene thermooxidation. Compound identification according to retention times and mass spectra, except for those marked with an asterisk, identified according to mass spectra only.

\section{Compound}

\section{Hydrocarbons}

Ethene

Propene

Isobutene *

Pentadiene*

2,4-Dimethyl-1-pentene*

Dimethylbenzene *

Alcohols

Methanol

2-Methyl-2-propen-1-oi

Ethane

Propane

Butane

2-Methyl-1-pentene*

5-Methyl-1-heptene*

Ethers

2-Methylfuran *

Ethanol

Aldehydes

Formaldehyde

Acrolein

Methacrolein

Butanal *

3-Methylpentanal *

Octanal *

Decanal *

Ketones

Ethenone*

3-Buten-2-one*

1-Hydroxy-2-propenone

3-Methyl-3-buten-2-one*

2-Pentanone

1-Cyclopropyl-2-propanone *

4-Methyl-2-pentanone*

2,5-Dimethylfuran

Acids

Formic acid

Propionic acid

Acetaldehyde

Propanal

2-Methylpropanal *

2-Vinylcrotonaldehyde *

3-Methylhexanal *

Nonanal ${ }^{*}$

\section{Acetone \\ 2-Butanone \\ 1-Cyclopropylethanone \\ 3-Penten-2-one* \\ 2,3-Butanedione* \\ 2,4-Pentanedione \\ 4-Methyl-2-heptanone*}

Table 4. Relative amounts of the degradation products ( $\mathrm{mol} / 100 \mathrm{~mol}$ of water) formed by the oxidation of polypropylene (without additives) at $220^{\circ} \mathrm{C}$ and $280^{\circ} \mathrm{C}$. ${ }^{\text {a }}$

\begin{tabular}{lcc}
\hline \multirow{2}{*}{ Compound } & \multicolumn{2}{c}{ Degradation temperature } \\
\cline { 2 - 3 } & $220^{\circ}$ & $280^{\circ}$ \\
\hline Water & 100 & 100 \\
Acetaldehyde & 0.92 & 0.98 \\
Formaldehyde & 0.60 & 0.76 \\
Acetone & 0.44 & 0.40 \\
Acetic acid & 0.36 & 0.40 \\
$\alpha$-Methylacrolein & 0.26 & 0.24 \\
2-Pentanone & 0.05 & 0.06 \\
\hline
\end{tabular}

a Relative standard deviation on the order of $15 \%$. logy has been described elsewhere $(2,3)$. The oxidation was performed in a reaction tube (inner diameter $22 \mathrm{~mm}$ ) with an air flow of $34 \mathrm{ml} / \mathrm{min}(2)$. The PP samples were heated for $2 \mathrm{~min}$ at 220 or $280^{\circ} \mathrm{C}$.

Infrared (IR) spectra of the PP films were recorded with a Perkin-Elmer 297 spectrophotometer.

Weight measurements of the polymer films before and after oxidation were performed with an electrobalance (Cahn model 4100). 


\section{Industrial hygiene measurements}

The measurements in the plastics industry were focused on substances identified in the analytical experiments. In addition the total amount of carboxylic compounds, carbonyl compounds (aldehydes and ketones), aerosols, peroxides, and free radicals was determined. The sampling and analysis were conducted with methods described earlier (3). Four plants with injection molding, extrusion, and welding machinery were included in the study. The compositions of the processed PP remained unknown, but all of them contained antioxidants. The processing temperatures ranged from 200 to $240^{\circ} \mathrm{C}$. The samples were collected in the vicinity of the machinery $(0.5-1.0 \mathrm{~m})$ at the height of the breathing zone $(1.5 \mathrm{~m})$. The machinery was equipped with local exhaust in the case of injection molding only.

\section{Biological experiments}

The plastic (Tenite, Eastman, United States, with unknown antioxidants) was degraded in air at $260^{\circ} \mathrm{C}$ or $310^{\circ} \mathrm{C}$ as described in our study on polyethylene and styrene plastics (3). Male Wistar rats (250$300 \mathrm{~g})$ were exposed to the products for $6 \mathrm{~h} / \mathrm{night}, 5$ nights/week. The rats were decapitated, and the lungs, brain, kidneys, and liver were removed immediately and analyzed as described earlier (3). The methods used for analyzing the exposure air were similar to those used in the industrial measurements.

\section{Results}

\section{Thermal degradation in air}

A total of 47 compounds were identified with GC-MS in the thermal degradation of PP in air (table 2). The amounts of some of the oxygen-containing compounds are shown in table 3 . Acetaldehyde, acetic acid, acetone, formaldehyde, and $\alpha$-methylacrolein were the most abundant degradation products. Their relative amounts appeared to be practically independent of the degradation temperature, as shown in table 4.

Isothermic thermogravimetric analysis at $250^{\circ} \mathrm{C}$ (figure 1) showed the stabilizing effect of the antioxidants. For example the plastic containing $1 \%$ antioxidants did not show a loss of weight for the first $11 \mathrm{~min}$, while the unstabilized sample began to degrade already after $4.5 \mathrm{~min}$. At $280^{\circ} \mathrm{C}$ the degradation of stabilized plastics started after $7.5 \mathrm{~min}$.

For the IR analysis, the sample was oxidized in air at 250 or $280^{\circ} \mathrm{C}$ for $2-3 \mathrm{~min}$. The most prominent spectral change was the appearance of absorption at $1,700-1,800 \mathrm{~cm}^{-1}$ (carbonyls). The IR spectra of unprotected PP showed strong carbonyl absorption already after a 2 -min oxidation at $250^{\circ} \mathrm{C}$, whereas no changes could be detected in the sample with an antioxidant after similar treatment (figure 2). The lat- ter spectrum seemed to be unchanged even after $2 \mathrm{~min}$ at $280^{\circ} \mathrm{C}$. The protected sample was, however, oxidized after $3 \mathrm{~min}$ at $280^{\circ} \mathrm{C}$.

The effect of antioxidants on the emission of formaldehyde, acetaldehyde, and acetone was studied with GC-MS. The emission of acetone from the heated plastics is shown in figure 3 , with heating at various temperatures for $2 \mathrm{~min}$. The results show the differing protectiveness of the two antioxidants. The diminished formation of formaldehyde, acetaldehyde, and acetone in the presence of an antioxidant is displayed in figure 4 . The amount of volatiles was smaller from the antioxidant-protected PP samples than from the unprotected ones; the relative amounts of individual volatiles nevertheless remained almost unchanged (table 5).

\section{Industrial hygiene measurements}

The results of the industrial hygiene measurements are shown in table 6 .

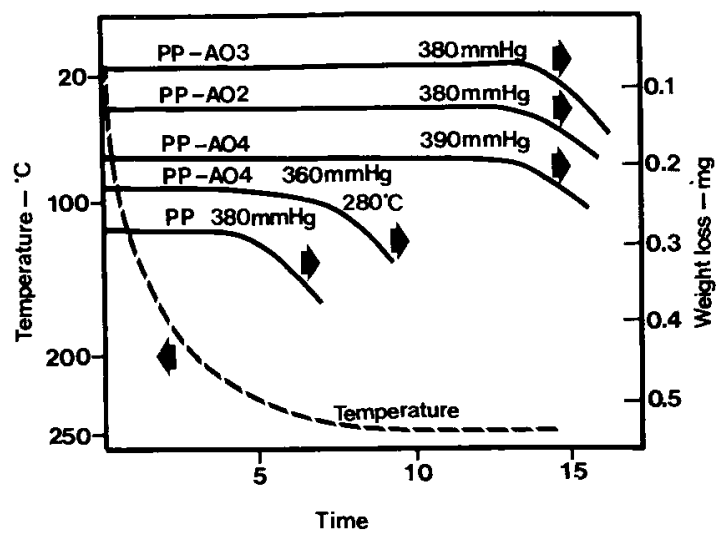

Figure 1. Thermogravimetric measurement of polypropylene degradation. Effect of various antioxidants (AO, see table 1$)$ on the process. Although in the same scale, the curves have been drawn from different apparent origins to make the weight losses more perceptible. $(1 \mathrm{mmHg}=133.3 \mathrm{~Pa})$

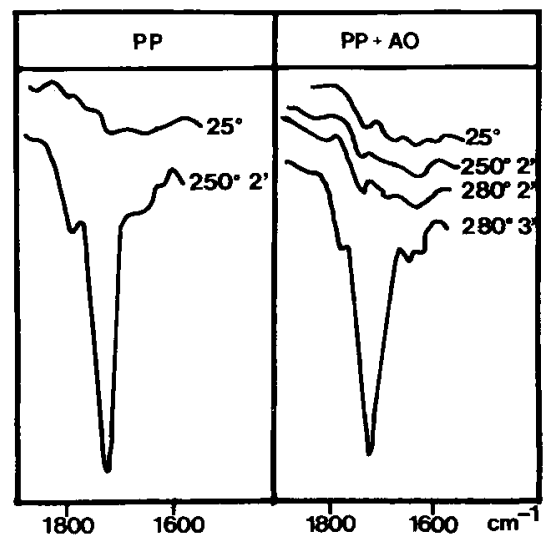

Figure 2. Infrared spectra of polypropylene with and without antioxidant before oxidation $\left(25^{\circ} \mathrm{C}\right)$ and after oxidation $\left(250^{\circ} \mathrm{C}\right.$ and $280^{\circ} \mathrm{G}$ ). 


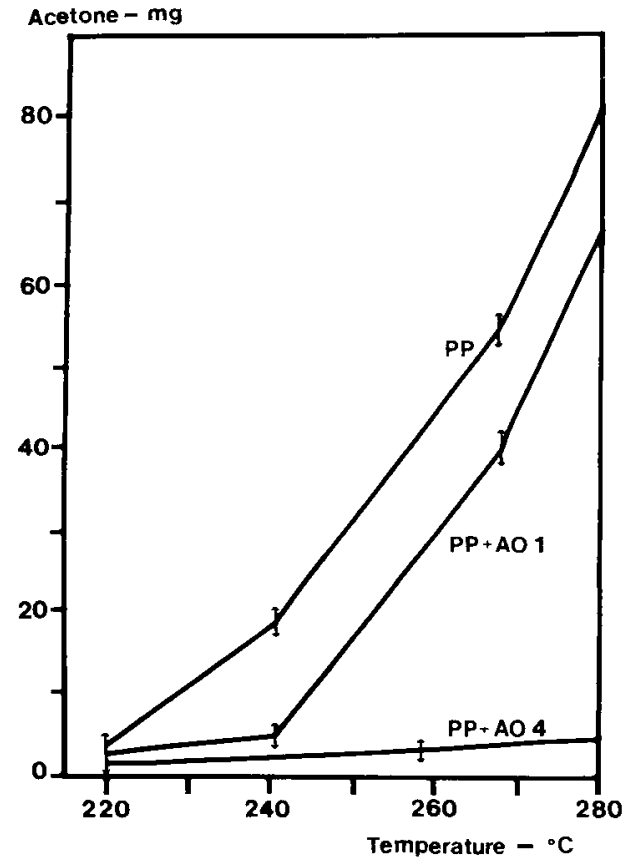

Figure 3. Effect of antioxidant on the formation of acetone during the oxidation ( $2 \mathrm{~min}$ ) of polypropylene at various temperatures.

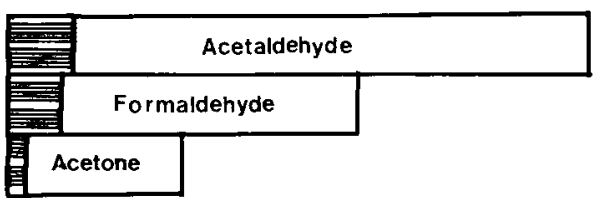

Figure 4. Emission of acetaldehyde, formaldehyde, and acetone during the oxidation of polypropylene at $280^{\circ} \mathrm{C}$ $(2 \mathrm{~min})$. The total area of the bars represents amounts emitted from unprotected polymer and the shaded parts the amounts from protected plastic ( $A O 4$, see table $1 ; 1 \%$ weight/weight).
Table 5. Relative amount (mol/mol of acetaldehyde) of evolved formaldehyde, acetaldehyde, and acetone in the oxidation of polypropylene with and without antioxidant. ${ }^{a}$

\begin{tabular}{lcc}
\hline Compound & $\begin{array}{c}\text { Polypropylene } \\
\text { without } \\
\text { antioxidant }\end{array}$ & $\begin{array}{c}\text { Polypropylene } \\
\text { with } \\
\text { antioxidant } \\
\text { AO4b }\end{array}$ \\
\hline Acetaldehyde & 1.0 & 1.0 \\
Formaldehyde & 0.79 & 0.61 \\
Acetone & 0.35 & 0.3 \\
\hline
\end{tabular}

a Relative standard deviation on the order of $15 \%$.

b See table 1 for contents of AO4.

Hydrocarbons with low molecular weights, alcohols, and esters were not detected in the industrial air. The total amount of aldehydes and ketones (calculated as carbonyl groups) was 0.8 (SEM 0.02) $\mathrm{mg} / \mathrm{m}^{3}$ in the four processing plants. The highest single value of $1.2 \mathrm{mg} / \mathrm{m}^{3}$ was measured during welding work. The concentration of formaldehyde was 0.05 (SEM 0.01$) \mathrm{mg} / \mathrm{m}^{3}(0.04 \mathrm{ppm})$ and the amount of acetaldehyde remained below our detection limit of $0.02 \mathrm{mg} / \mathrm{m}^{3}$. The highest mean concentration of formaldehyde $\left(0.1 \mathrm{mg} / \mathrm{m}^{3}\right)$ occurred during welding. We were unable to show the presence of acrolein or $\alpha$-methylacrolein at the workplaces. The concentration of acetone was 0.3 (SEM 0.3) $\mathrm{mg} / \mathrm{m}^{3}$, and the highest values $\left(0.6 \mathrm{mg} / \mathrm{m}^{3}\right)$ were also in this case encountered during welding. The total concentration of acid was 0.2 (SEM 0.1$) \mathrm{mg} / \mathrm{m}^{3}$ (calculated as carboxylic groups) and that of formic acid $0.1(\mathrm{SEM} 0.03) \mathrm{mg} / \mathrm{m}^{3}$ and acetic acid 0.05 (SEM $0.03) \mathrm{mg} / \mathrm{m}^{3}$. The amounts of reactive degradation intermediates (peroxides and free radicals) and carbon monoxide were below the detection limits $(0.3$ $\mathrm{mg} / \mathrm{m}^{3}$ and $0.01 \mathrm{ppm}$, respectively).

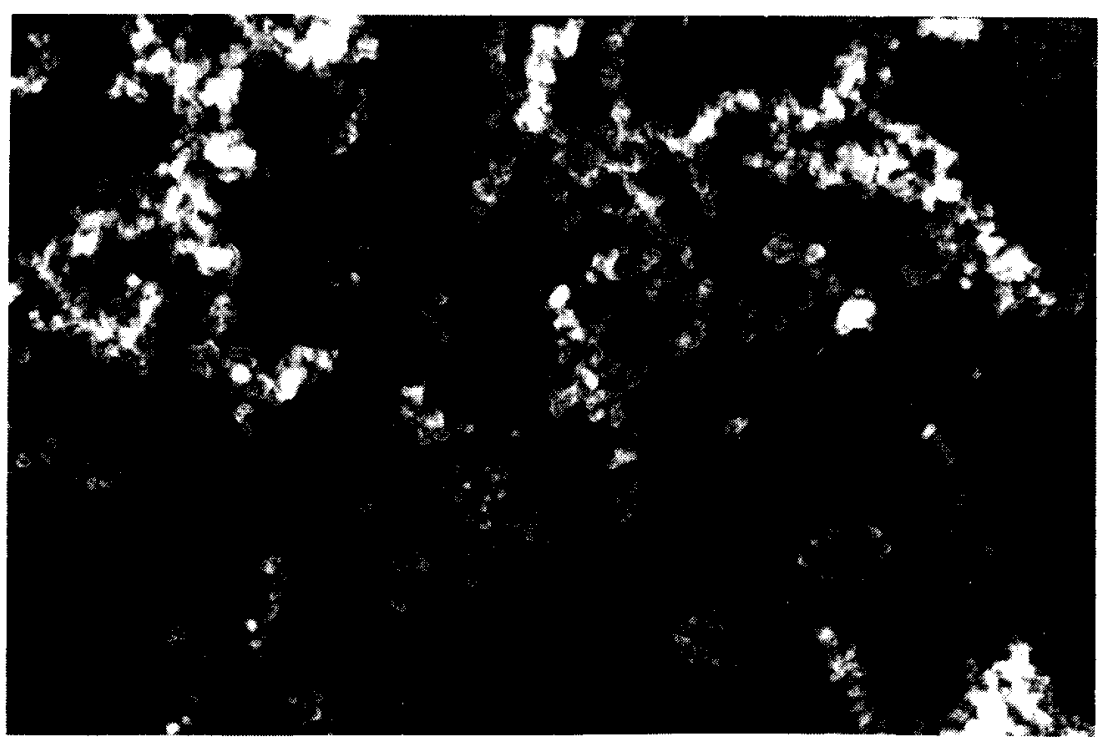

Figure 5. Scanning electronmicrograph of polypropylene fume $(10,000 \times)$. 
Table 6. Concentrations of degradation products in the industrial processing of polypropylene. [SEM $=$ standard error of the mean (used when comparing different workplaces), SD = standard deviation (used when comparing the values in an individual workplace)]

\begin{tabular}{|c|c|c|c|c|c|}
\hline \multirow[t]{2}{*}{ Product } & \multicolumn{2}{|c|}{$\begin{array}{c}\text { Average } \\
\text { concentration } \\
\left(\mathrm{mg} / \mathrm{m}^{3}\right)\end{array}$} & \multicolumn{2}{|c|}{$\begin{array}{c}\text { Highest } \\
\text { concentration } \\
\left(\mathrm{mg} / \mathrm{m}^{3}\right)\end{array}$} & \multirow{2}{*}{$\begin{array}{c}\text { Number } \\
\text { of } \\
\text { samples/plant }\end{array}$} \\
\hline & Mean & SEM & Mean & $S D$ & \\
\hline Aerosol & 0.9 & 0.7 & 2.2 & 1.1 & 8 \\
\hline Total amount of carbonyl compounds ${ }^{a}$ & 0.8 & 0.02 & 1.2 & 1.2 & 4 \\
\hline Formaldehyde & 0.05 & 0.01 & 0.1 & 0.1 & 4 \\
\hline Acetaldehyde & 0.02 & 0.01 & 0.02 & 0.01 & 4 \\
\hline Acetone & 0.3 & 0.3 & 0.6 & 0.1 & 4 \\
\hline Total acids ${ }^{\mathrm{b}}$ & 0.2 & 0.1 & 0.3 & 0.2 & 2 \\
\hline Formic acid & 0.1 & 0.03 & 0.1 & 0.04 & 4 \\
\hline Acetic acid & 0.05 & 0.03 & 0.1 & 0.05 & 4 \\
\hline
\end{tabular}

a Calculated as carbonyl groups.

b Calculated as carboxylic groups.

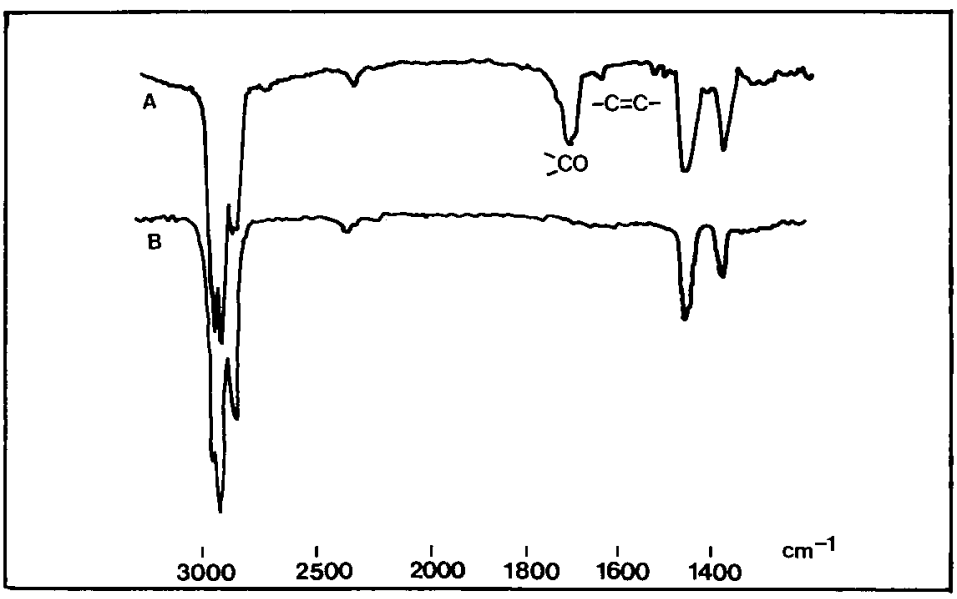

Figure 6. Infrared spectra of polypropylene aerosol (A) and paraffin oil (B).

The electron microscopy showed that the particle size of the aerosols taken on Nuclepore filters was in general smaller than the pore size $(0.2 \mu \mathrm{m})$ of the filters (figure 5). The aerosols resembled closely the PP aerosols (2). The mean concentration of the aerosols in our industrial measurements was 0.9 (SEM $0.7) \mathrm{mg} / \mathrm{m}^{3}$. During welding, the mean concentration was $2.2 \mathrm{mg} / \mathrm{m}^{3}$. IR spectroscopy of the aerosol indicated the presence of double bonds and carbonyl groups, products of the oxidation of PP (figure 6).

\section{Biochemical results}

The concentrations of the degradation products in the exposures are given in table 7 . The exposures decreased the concentration of reduced nonprotein sulfhydryl groups (mainly glutathione) in the liver, lungs, and brain of the exposed rats (table 8 ). The microsomal monooxygenation activity (7-ethoxycoumarin O-deethylase) was increased in the liver and the kidney but diminished in the lung (table 8). No neurochemical effects on the brain could be detected in contrast to our earlier results with low-density polyethylene (5).
Table 7. Concentrations of degradation products of polypropylene in animal exposures.

\begin{tabular}{|c|c|c|}
\hline \multirow{2}{*}{ Product } & \multicolumn{2}{|c|}{ Degradation temperature } \\
\hline & $260^{\circ} \mathrm{C}$ & $300^{\circ} \mathrm{C}$ \\
\hline Carbon monoxide & $2 \quad \mathrm{ppm}$ & $50 \mathrm{ppm}$ \\
\hline Formaldehyde & $0.9 \mathrm{ppm}$ & $7.6 \mathrm{ppm}$ \\
\hline Acrolein & $0.01 \mathrm{ppm}$ & $0.5 \mathrm{ppm}$ \\
\hline Acetaldehyde & $1.1 \mathrm{ppm}$ & $11.9 \mathrm{ppm}$ \\
\hline Total carbonyl groups & $\mathrm{ppm}$ & $52 \mathrm{ppm}$ \\
\hline Acetone & $0.2 \mathrm{ppm}$ & $5.2 \mathrm{ppm}$ \\
\hline Formic acid & $1.9 \mathrm{ppm}$ & $5.1 \mathrm{ppm}$ \\
\hline Acetic acid & $1.5 \mathrm{ppm}$ & $6.4 \mathrm{ppm}$ \\
\hline Aerosols & $21 \mathrm{mg} / \mathrm{m}^{3}$ & $400 \mathrm{mg} / \mathrm{m}^{3}$ \\
\hline
\end{tabular}

a The values are means of four air samples. The relative standard deviation in determinations was on the order of $15 \%$.

\section{Discussion}

The mechanism of PP oxidation has been studied extensively [see, eg, the report of Matveeva et al (4)]. The oxidation is started by the reaction of oxygen with the polymer and the formation of hydroperoxides:

$$
\mathrm{RH}+\mathrm{O}_{2} \rightarrow \mathrm{ROOH},
$$

(reaction 1) 
Table 8. Effect of thermal degradation products of polypropylene on glutathione level in the rat.

\begin{tabular}{|c|c|c|c|c|c|c|c|c|}
\hline \multirow{3}{*}{ Exposure } & \multicolumn{8}{|c|}{ Glutathione $^{\mathrm{a}}$} \\
\hline & \multicolumn{2}{|c|}{ Liver } & \multicolumn{2}{|c|}{ Lung } & \multicolumn{2}{|l|}{ Kidney } & \multicolumn{2}{|c|}{ Brain } \\
\hline & Mean & SD & Mean & SD & Mean & SD & Mean & SD \\
\hline \multicolumn{9}{|c|}{ Degradation temperature $260^{\circ} \mathrm{C}$} \\
\hline $\begin{array}{l}\text { Control } \\
\text { Two weeks } \\
\text { Three weeks }\end{array}$ & $\begin{array}{l}8.14 \\
7.56 \\
7.63\end{array}$ & $\begin{array}{l}0.54 \\
0.43^{*} \\
0.49^{*}\end{array}$ & $\begin{array}{l}1.43 \\
1.50 \\
1.42\end{array}$ & $\begin{array}{l}0.23 \\
0.06 \\
0.10\end{array}$ & $\begin{array}{l}4.06 \\
4.04 \\
4.01\end{array}$ & $\begin{array}{l}0.13 \\
0.19 \\
0.19\end{array}$ & $\begin{array}{l}2.2 \\
2.0 \\
2.0\end{array}$ & $\begin{array}{l}0.02 \\
0.24 \\
0.02^{*}\end{array}$ \\
\hline \multicolumn{9}{|c|}{ Degradation temperature $310^{\circ} \mathrm{C}$} \\
\hline $\begin{array}{l}\text { Control } \\
\text { Three nights } \\
\text { Three weeks }\end{array}$ & $\begin{array}{l}7.99 \\
6.76 \\
6.94\end{array}$ & $\begin{array}{l}0.43 \\
0.26^{\star} \\
0.45^{\star}\end{array}$ & $\begin{array}{l}1.93 \\
1.56 \\
1.51\end{array}$ & $\begin{array}{l}0.30 \\
0.15^{\star} \\
0.11^{\star}\end{array}$ & $\begin{array}{l}3.65 \\
3.47 \\
3.53\end{array}$ & $\begin{array}{l}0.21 \\
0.18 \\
0.05\end{array}$ & $\begin{array}{l}2.3 \\
2.0 \\
1.9\end{array}$ & $\begin{array}{l}0.11 \\
0.04 \\
0.05^{*}\end{array}$ \\
\hline
\end{tabular}

a Results are from five rats per group, and the concentrations are given in nanomoles per gram of tissue.

* $p<0.05$, Student's t-test.

Table 9. Effect of the thermal degradation products of polypropylene on microsomal monooxygenase (7-ethoxycoumarin O-deethylase) activity in the rat.

\begin{tabular}{|c|c|c|c|c|c|c|}
\hline \multirow{3}{*}{ Exposure } & \multicolumn{6}{|c|}{ 7-Ethoxycoumarin O-deethylase ${ }^{a}$} \\
\hline & \multicolumn{2}{|c|}{ Liver } & \multicolumn{2}{|c|}{ Kidney } & \multicolumn{2}{|c|}{ Lung } \\
\hline & Mean & SD & Mean & SD & Mean & SD \\
\hline \multicolumn{7}{|c|}{ Degradation temperature $260^{\circ} \mathrm{C}$} \\
\hline $\begin{array}{l}\text { Control } \\
\text { Two weeks } \\
\text { Three weeks }\end{array}$ & $\begin{array}{l}1.47 \\
1.06 \\
1.46\end{array}$ & $\begin{array}{l}0.23 \\
0.11 \\
0.07\end{array}$ & $\begin{array}{l}0.016 \\
0.011 \\
0.019\end{array}$ & $\begin{array}{l}0.004 \\
0.003 \\
0.002^{*}\end{array}$ & $\begin{array}{l}0.209 \\
0.133 \\
0.129\end{array}$ & $\begin{array}{l}0.052 \\
0.016^{*} \\
0.014^{*}\end{array}$ \\
\hline \multicolumn{7}{|c|}{ Degradation temperature $310^{\circ} \mathrm{C}$} \\
\hline $\begin{array}{l}\text { Control } \\
\text { Two nights } \\
\text { Three weeks }\end{array}$ & $\begin{array}{l}1.03 \\
1.41 \\
1.18\end{array}$ & $\begin{array}{l}0.20 \\
0.12^{\star} \\
1.18\end{array}$ & $\begin{array}{l}0.019 \\
0.023 \\
0.029\end{array}$ & $\begin{array}{l}0.001 \\
0.001^{\star} \\
0.002^{\star}\end{array}$ & $\begin{array}{l}0.194 \\
0.070 \\
0.071\end{array}$ & $\begin{array}{l}0.022 \\
0.018^{*} \\
0.012^{*}\end{array}$ \\
\hline
\end{tabular}

a Results are from five animals per group, and the activities are given in nanomoles per minute per milligram of microsomal protein.

$* p<0.05$, Student's t-test.

Peroxides react further to form free radicals:

$$
\mathrm{ROOH} \rightarrow \mathrm{RO}+. \mathrm{OH} \text {. }
$$

(reaction 2)

An alkoxy radical is very reactive and can abstract hydrogen atoms from the polymer. An alcohol and an alkyl radical is formed:

$$
\mathrm{RO} \cdot+\mathrm{R} \rightarrow \mathrm{ROH}+\mathrm{R} \cdot \text {. }
$$

Alkyl radicals react easily with oxygen, producing peroxy radicals:

$$
\mathrm{R} \cdot+\mathrm{O}_{2} \rightarrow \text { ROO. }
$$

(reaction 4)

These abstract hydrogen from the polymer:

$$
\mathrm{ROO} \cdot+\mathrm{R} \rightarrow \mathrm{ROOH}+\mathrm{R} \cdot \text {. }
$$

(reaction 5)

Hydroperoxides and alkyl radicals are formed. The fragmentation of alkoxy radicals is considered to be responsible for the formation of volatile products in the oxidation of PP:

$$
\text { RO. } \rightarrow \mathrm{R} \cdot+\text { volatile products. (reaction 6) }
$$

The fragmentation of alkoxy radicals has a comparatively low activation energy, and the emission of volatile products is therefore relatively insensitive to variations in temperature, as found in this study (table 3).

The most commun antioxidants are sterically hindered phenols (ANT-OH) which react with peroxy radicals and form stable antioxidant radicals (ANT-O- ):

$$
\mathrm{ROO}+\mathrm{ANT}-\mathrm{OH} \rightarrow \mathrm{ROOH}+\underset{(\text { reaction } 7 \text { ) }}{\mathrm{ANT}-\mathrm{O} \cdot}
$$

The deactivation of peroxy radicals slows down the propagation of the oxidation. The hydroperoxides $(\mathrm{ROOH})$ are nevertheless quite reactive (see reaction 2 ), and the protection against further degradation is not always adequate. Synergistic antioxidants such as organophosphites $\left(\mathrm{P}-(\mathrm{OR})_{3}\right)$ improve the protective effect through the reduction of hydroperoxides to alcohols:

$$
\begin{aligned}
\mathrm{ROOH}+\mathrm{P}-(\mathrm{OR})_{3} \rightarrow \mathrm{ROH}+\mathrm{O} & =\underset{(\text { reaction }}{\mathrm{P}-(\mathrm{OR})_{3}} .
\end{aligned}
$$

The formation of volatile products in the oxidation of antioxidant-containing [up to $1 \%$ (weight/ weight)] $\mathrm{PP}$ at temperatures above $200^{\circ} \mathrm{C}$ can be explained as follows: Hydroperoxides are unstable at these temperatures, and the rate of their decomposi- 
tion is presumably higher than the mobility of the organophosphite molecules in the polymer melt. Thus the hydroperoxides are not effectively inactivated (reaction 8 ). The industrial measurements showed that PP is degraded to some extent during processing. The degradation products included many compounds, and the concentrations of the individual contaminants were low in comparison with the current limit values. Only the concentration of aerosols seemed to be alarming. The concentration was approximately one-third of the Swedish hygienic standard $\left(3 \mathrm{mg} / \mathrm{m}^{3}\right)$ for oil fume, one-half of the American threshold limit value $\left(2 \mathrm{mg} / \mathrm{m}^{3}\right)$ for paraffin wax fumes, and almost the same as the Finnish value for paraffin fumes $\left(1 \mathrm{mg} / \mathrm{m}^{3}\right)$. An IR spectrum of the aerosol closely resembles that of paraffin oil (figure 6). The aerosol contains double bonds and carbonyl groups as a result of thermooxidation and/or the inclusion of oxidized compounds with low molecular weights (aldehydes, ketones, acids). Aerosols consist of small respirable particles (diameter less than $0.2 \mu \mathrm{m}$ ) and might cause irritation (the oxidized groups and the dissolved compounds with low molecular weights).

The industrial measurements were conducted under normal processing conditions. The disturbances in the process and in the ventilation may have given rise to higher concentrations of contaminants than the measured values. This possibility can be concluded from the fact that, during welding, where the degradation temperatures are significantly higher, the measured concentrations were the highest.

The concentration of degradation products encountered in industry was appreciably lower than that found in the laboratory analyses. One explanation is provided by surface area : volume ratio. The specimen used in the laboratory studies had a much higher surface : volume ratio than the industrially extruded plastic articles.

The analytical and hygienic results indicate that it is not necessary to measure many degradation products of PP for hygienic evaluations in industry. The sampling and analysis of the following indicator substances appears sufficient: (i) formaldehyde or the total concentration of carbonyl compounds, (ii) formic and acetic acid, and (iii) the amount of aerosols.
The toxicologic results show that PP fumes are biologically active, $\mathrm{cf}$, the depletion of reduced nonprotein sulfhydryls (mainly glutathione) and the effects on foreign compound metabolism. [For a discussion of the subject see the report of Zitting (6).] An interesting feature is however that, although the concentrations of the measured compounds were higher than in our PP exposures $(3,5)$, the effects were milder. The reason for this discrepancy remains obscure, and it is possible that we do not know the effective compounds and/or the various combined effects of the atmospheric contaminants in PP fume exposure.

\section{Acknowledgments}

We thank the Swedish Work Environment Fund for its financial support and Ms U Peltonen, Ms T Hankimo, Ms M Virtanen, and Mr Y Peltonen for their skilled technical assistance.

\section{References}

1. Barabas K, Iring M, Laszlo-Hedvig S, Kelen T, Tüdös F Study of the thermal oxidation of polyolefines - VII Volatile products of polypropylene thermal oxidation. Eur Polymer J 14 (1978) 405-411.

2. Hoff A, Jacobsson S. Thermal oxidation of polypropylene in the temperature range of $120-280^{\circ} \mathrm{C}$. $\mathrm{J} \mathrm{Appl}$ Polymer Sci 29 (1984) 465-480.

3. Hoff A, Jacobsson S, Pfäffli P, Zitting A, Frostling $H$. Degradation products of plastics: Polyethylene and styrene-containing thermoplastics - Analytical, occupational and toxicologic aspects. Scand J Work Environ Health 8 (1982): suppl 2, 60 p.

4. Matveeva EM, Khinkis SS, Cvetkova AI, Balandina VA. Starenie poliolefinov: Termookislitelnaja destruktsija poliolefinov. Plast massy 1 (1963) $2-5$.

5. Zitting A, Savolainen $H$. Neurotoxic effects of the oxidative thermal degradation products from low density polyethylene. Fire Mater 3 (1979) 80-83.

6. Zitting A, Savolainen $\mathrm{H}$. Effects of single and repeated exposures to thermo-oxidative degradation products of poly(acrylonitrile-butadiene-styrene) (ABS) on rat lung, liver, kidney and brain. Arch Toxicol 46 (1980) 295304.

7. Introduction. Mod Plast Int June (1982) 11.

Received for publication: 14 December 1983 